Фармацевтичний менеджмент, маркетинг та логістика

Pharmaceutical management, marketing and logistics

Рекомендована д. фармац. наук, проф. В. В. Трохимчуком

УДК 614.272:339:616.14-007.63

\title{
МАРКЕТИНГОВИЙ АНАЛІЗ АСОРТИМЕНТУ ЛІКАРСЬКИХ ПРЕПАРАТІВ ДЛЯ ЛІКУВАННЯ ВАРИКОЗНОГО РОЗШИРЕННЯ ВЕН І ЗАПАЛЬНИХ ЗАХВОРЮВАННЬ СУГЛОБІВ
}

\author{
๑л. С. Сімонян, І. М. Грубник \\ Національний фармацевтичний університет, Харків
}

\begin{abstract}
Резюме: досліджено асортимент лікарських засобів для застосування при варикозному розширенні вен і запальних захворювань суглобів на фармацевтичному ринку України. Встановлено, що в досліджуваному асортименті препаратів референтної групи 70 \% від загальної кількості складають гелі, 25 \% мазі і 5 \% креми.
\end{abstract}

Ключові слова: маркетинговий аналіз, лікарські засоби, варикозне розширення вен.

Вступ. Варикоз - серйозне захворювання, при якому вени втрачають свою еластичність, розтягуються і розширюються. До цього призводить природжена слабкість венозних стінок і неповноцінність їх клапанів, що призводить до утруднення течії крові і підвищення внутрішньосудинного тиску [1, 3, 6, 7, 8]. При розробці нового лікарського засобу аналіз фармацевтичного ринку та цінових характеристик лікарських засобів (ЛЗ) набуває особливого значення.

На підставі вищезазначеного метою нашої роботи став маркетинговий аналіз вітчизняного фармацевтичного ринку ЛЗ. Враховуючи попередньо визначені характеристики нового препарату, що пропонується до розробки та подальшого впровадження, необхідно було визначити основні показники асортименту, які підлягають подальшому дослідженню.

Завдяки діючим речовинам, які входять до складу гелю «Живітан», а саме сухого екстракту насіння кінського каштану (есцин) та екстракту окопника, даний препарат пропонується застосовувати при варикозному розширенні вен, травмах, забоях, запальних захворюваннях суглобів. Крім цього, даний препарат пропонують у м'якій лікарській формі. Тому основними показниками, що характеризують асортимент ЛЗ, стали фармакотерапевтичні характеристики препаратів та їх лікарські форми [5].

Методи дослідження. Аналіз асортименту препаратів проводили згідно з Державним реєстром лікарських засобів України та класифікаційною системою АТС. Об'єктами дослідження були засоби, застосовують при варикозному розширенню вен та запальних захворюваннях суглобів. Як інформаційні джерела використовували Державний реєстр лікарських засобів України, Компендіум 2007-2014 рр. [2, 4].
Результати й обговорення. Відповідно до уніфікованої анатомо-терапевтичної та хімічної класифікаційної системи АТC (Anatomical Therapeutic Chemical) ЛЗ, що досліджуються, відносять до груп С05В - засоби, що застосовуються при варикозному розширенні вен, С05С - капіляростабілізуючі засоби та М02A - засоби, що застосовуються місцево при суглобовому та м'язовому болю.

За даними Державного експертного центру МОЗ України, станом на вересень 2014 року, в Україні було зареєстровано 3 торговельних назви лікарських препаратів (ЛП) 3 групи C05B, 3 групи С05С - 9, а з групи М02A - 8 з урахування форм випуску. Аналіз зареєстрованих торговельних назв ЛЗ за фірмами-виробниками показав, що основну частину асортименту формують препарати європейських фармацевтичних компаній (рис. 1). Співвідношення торговельних назв ЛЗ, що включають досліджувані групи, іноземного та вітчизняного виробництва становлять 65 до $35 \%$.

Препарати, які зареєстровані на українському фармацевтичному ринку капіляростабілізуючої дії, що застосовуються при варикозному розширенні вен місцево (при суглобовому та м'язовому болю), станом на 2007-2014 рр. представлені на рисунку 1

На оптовому фармацевтичному ринку препаратів, що застосовуються при варикозному розширені вен, з 2007-2010 рр. було зареєстровано 3 торговельних назви ЛЗ (з урахуванням форм випуску), у 2011-2013 рр. - 2 лП, а у 2014 р. - 3 лП. За групою капіляростабілізуючих засобів у 2007 р. було зареєстровано 7 лП (з урахуванням форм випуску), у 2008 та 2009 рр. - 8 ЛП, у 2010-2011 рр. по 9 ЛП, у 2012-2013 pp. - 8 ЛП, у 2014 р. - 9 ЛП. У групі засобів, що

ISSN 2312-0967. Фармацевтичний часопис. 2015. № 1 
Фармацевтичний менеджмент, маркетинг та логістика

Pharmaceutical management, marketing and logistics

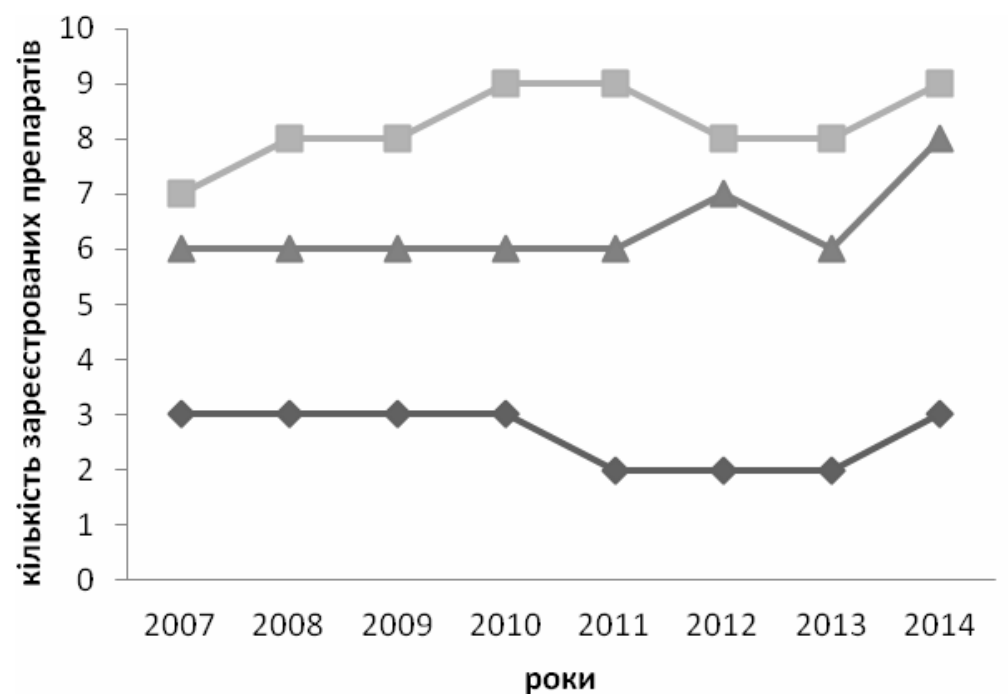

—C05BA - засоби, що застосовуються при варикозному розширенні вен

- $\mathrm{C05CX}$ - капіляростабілізуючі засоби

$-\mathrm{M02AX}$ - засоби, що застосовуються місцево при суглобовому та м'язовому болю

Рис. 1. Кількість пропозицій препаратів противарикозної дії на оптовому ринку лЗ за 2007-2014рр.

застосовуються місцево при суглобовому та м'язовому болю, станом на 2007-2011 рр. були зареєстровані 6 торговельних назви ЛП (з урахуванням форм випуску), у 2012 році - 7 найменувань ЛП, а у 2014 році - 8 найменувань ЛП. Поступове збільшення торговельних назв ЛП, безумовно, слід оцінити як позитивну тенденцію.

Далі нами були проаналізовано співвідношення пропозицій вітчизняних та іноземних виробників на українському фармацевтичному ринку ЛЗ (рис. 2).

Слід відзначати, що за 2007-2014 рр. спостерігається незначне збільшення пропозицій вітчизняних ЛЗ, лише до 5 \%, що вказує на необхідність подальшого росту та розвитку вітчизняного фармацевтичного ринку ЛЗ, у м'яких лікарських формах, які застосовуються при варикозному розширенні вен, забоях та запальних захворюваннях суглобів, у склад яких вхо- дить есцин та екстракт окопника.

ЛП, що застосовуються при варикозному розширені вен, забоях та запальних захворюваннях суглобів, вітчизняного виробництва зареєстрували 3 компанії: ТОВ Натурпродукт-Вега (чотири торговельні найменування, з урахуванням форм випуску), Тернопільський ФФ (дві торговельні назви) та ПАО Лубнифарм (одне торговельне найменування).

Серед іноземних компаній лідерами є компанія Heel, Німеччина (3 ЛП з урахуванням форм випуску) та Sandoz, Швейцарія (2 ЛП). На даний час на вітчизняному фармацевтичному ринку лп фармакотерапевтичних груп, що досліджуються, зареєстрували 12 фармацевтичних компаній, 3 них 9 компаній іноземні. Таким чином, український ринок ЛП характеризується залежністю від імпорту ЛП, що слід оцінити як вкрай негативну тенденцію (рис. 3).
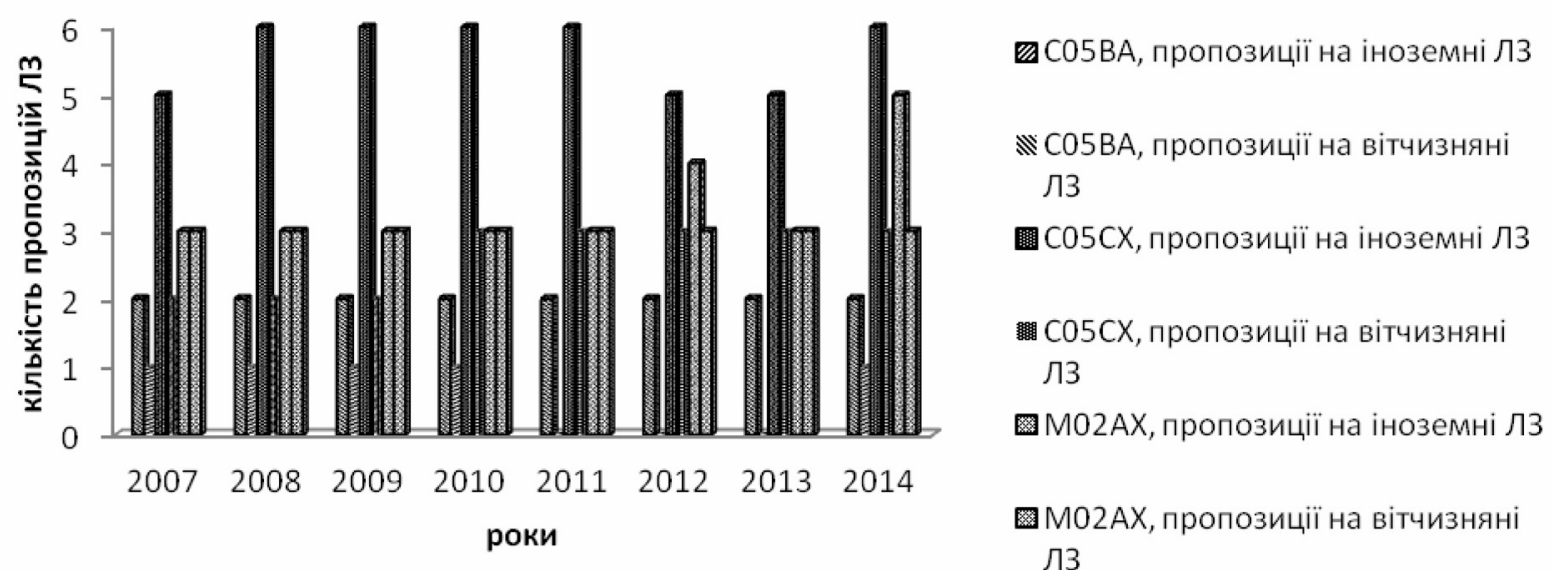

Рис. 2. Структура пропозицій на ЛЗ при варикозному розширенні вен, забоях, запальних захворюваннях суглобів за 2007-2014 рр.

ISSN 2312-0967. Pharmaceutical review. 2015. № 1 
Фармацевтичний менеджмент, маркетинг та логістика

Pharmaceutical management, marketing and logistics

Bosnalijek, Республіка Боснія-Герцеговина
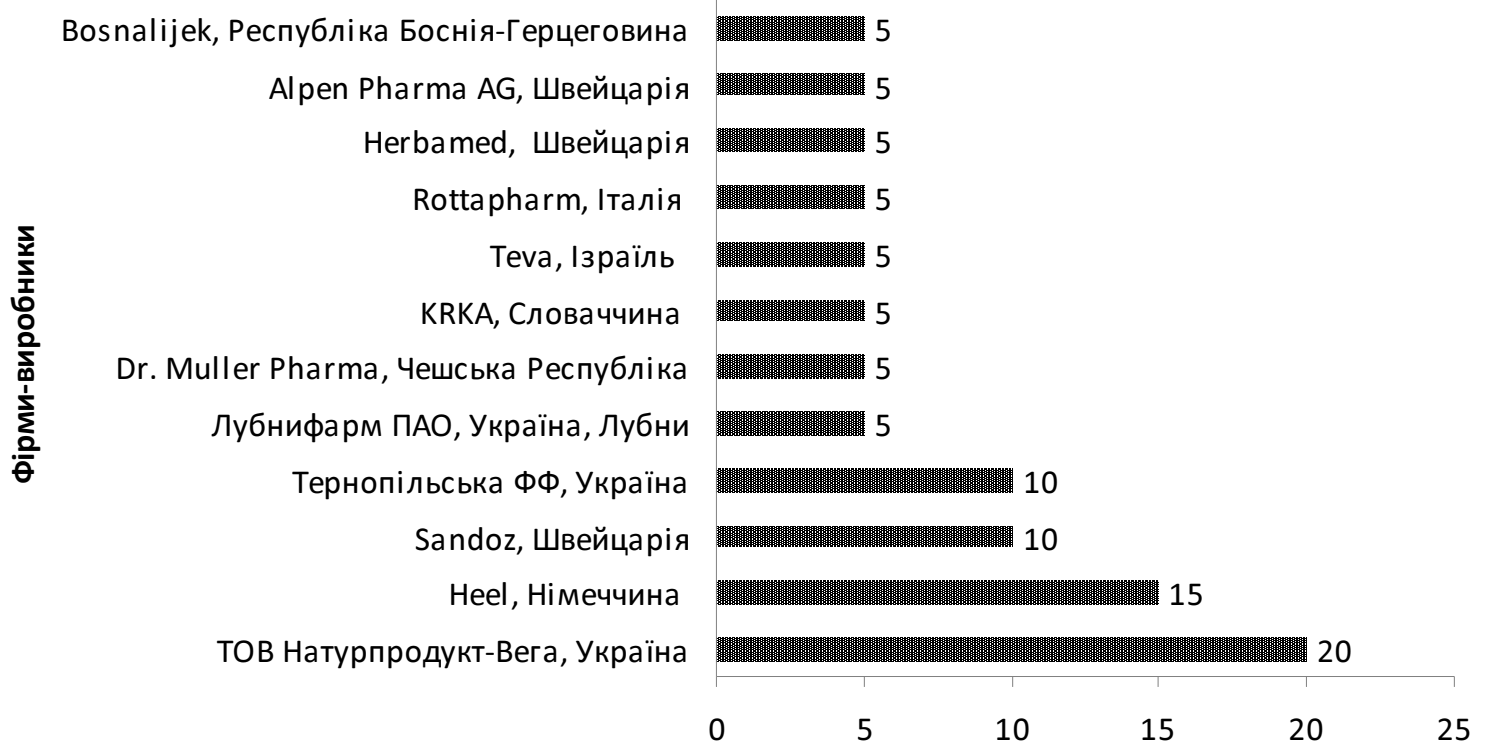

Питома вага, \%

Рис. 3. Кількість пропозицій препаратів противарикозної та капіляростабілізуючої дії та засобів, що застосовуються при суглобових та м'язових болях за фірмами виробниками (вересень 2014 р.).

За результатами аналізу структури пропозицій за фірмами-виробниками і даними реєстрації препаратів можна зазначити, що на оптовому ринку препаратів, які досліджуються, спостерігається домінування ЛЗ іноземного виробництва. Тому набуває важливого соціально-економічного значення впровадження програмних заходів імпортозаміщення.

Вирішення проблеми комплаєнса значною мірою залежить від вибору оптимальної лікарської форми. Оскільки референтна група препаратів складається 3 м'яких лікарських форм, наступним етапом наших досліджень був аналіз асортименту ЛП за представленою лікарською формою (мазі, гелі, креми). У досліджуваному асортименті препаратів, які застосовуються при варикозному розширенні вен, забоях та запальних захворюваннях суглобів, 70 \% від загальної кількості складають лікарські форми у вигляді гелів, 25 \% у вигляді мазей, та 5 \% складають креми (рис. 4).

Таким чином, виходячи з результатів проведених досліджень, можна стверджувати, що в умовах фінансово-економічної кризи та низькій платоспроможності населення, зростає потреба у підвищенні конкурентоспроможності вітчизняного виробництва за групами препаратів противарикозної та капіляростабілізуючої дії шляхом впровадження програм імпортозаміщення, що, в свою чергу, сприятиме зростанню доступності препаратів даного сегмента ринку.

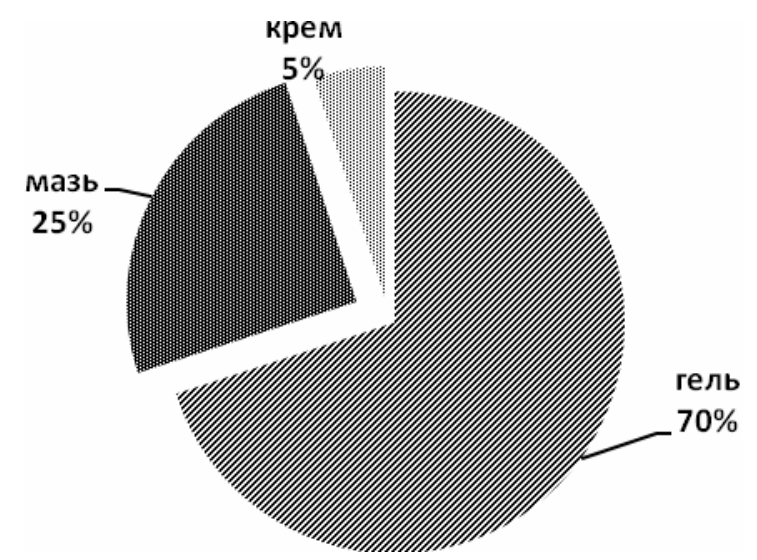

Рис. 4. Структура асортименту препаратів противарикозної та капіляростабілізуючої дії та засобів, що застосовуються при суглобових та м'язових болях за лікарськими формами.

ISSN 2312-0967. Фармацевтичний часопис. 2015. № 1 
Фармацевтичний менеджмент, маркетинг та логістика

Pharmaceutical management, marketing and logistics

Висновки. 1. Аналіз даних Державної реєстрації ЛЗ, що застосовуються при варикозному розширенні вен та при суглобовому та м'язовому болю, відносно фірм-виробників показав, що основну частку асортименту формують препарати європейських фармацевтичних компаній. Співвідношення торговельних назв зазначених груп ЛЗ іноземного та вітчизняного виробництва становить 65 до $35 \%$.

2. У досліджуваному асортименті препаратів референтної групи (противарикозної та капіляростабілізуючої дії та засобів, що застосовуються при суглобовому та м'язовому болях) 70 \% від загальної кількості складають гелі, 25 \% мазі та 5 \% креми.

\title{
Література
}

1. Богачев В. Ю. Системная фармакотерапия хронической венозной недостаточности нижних конечностей. Современное состояние вопроса / В. Ю. Богачев // РМЖ. - 2004. - № 17.

2. Державний реєстр лікарських засобів України. [Електронний ресурс]. - режим доступу: http:// vwvw.drlz.kiev.ua/

3. Золотухин И. А. Алгоритм лечения хронической венозной недостаточности нижних конечностей / И. А. Золотухин // Consilium-medicum. - 2005. - Т. 7, № 6.

4. Компендіум. [Електронний ресурс]. - Режим доступу: http://compendium.com.ua/

5. Науково-методичні підходи до проведення моніто-

рингу цін на лікарські засоби, що закуповуються за державними цільовими програмами / К. Л. Косяченко, А. С. Немченко, О. В. Коваленко, І. В. Кубарєва // Фармац. журн. - 2011. № 1 - С. 13-18.

6. Савельев В. С. Венозные трофические язвы: мифы и реальность / В. С. Савельев, А. Н. Кириенко, В. Ю. Богачев // Флеболимфология. - 2000. - № 11. - С. 5-10.

7. Яблоков Е. Г. Хроническая венозная недостаточность / Е. Г. Яблоков, А. И. Кириенко, В. Ю. Богачев. М.: Изд-во «Берег», 1999. - 128 с.

8. Eklof B. Revision of the CEAP classification. 10 years after its introduction in 1994 / B. Eklof // Medicographia. - 2006. - Vol. 28, № 2. - P. 175-180.

\section{МАРКЕТИНГОВЫЙ АНАЛИЗ АССОРТИМЕНТА ЛЕКАРСТВЕННЫХ ПРЕПАРАТОВ ДЛЯ ЛЕЧЕНИЯ ВАРИКОЗНОГО РАСШИРЕНИЯ ВЕН И ВОСПАЛИТЕЛЬНЫХ ЗАБОЛЕВАНИЙ СУСТАВОВ}

\author{
Л. С. Симонян, И. М. Грубник \\ Национальный фармацевтический университет, Харьков
}

Резюме: исследовано ассортимент лекарственных средств для применения при варикозном расширении вен и воспалительных заболеваний суставов на фармацевтическом рынке Украины. Установлено, что в исследуемом ассортименте препаратов референтной группы 70 \% от общего количества составляют гели, 25 \% мази и 5 \% кремы.

Ключевые слова: маркетинговый анализ, лекарственные средства, варикозное расширение вен.

\section{MARKETING ANALYSIS OF THE ASSORTMENT OF MEDICINES USED FOR VARICOSE VEINS AND INFLAMMATORY JOINT TREATMENT}

\section{S. Simonian, I. M. Grubnik \\ National University of Pharmacy, Kharkiv}

Summary: the assortment of medicines, used at varicose veins and inflammatory joint diseases on the Ukrainian pharmaceutical market was studied. It was found that in the studied range of reference group medicines $70 \%$ of the total amount make gels, $25 \%$ are ointments and $5 \%$ are creams.

Key words: marketing analysis, medicines, varicose veins. 